IRA-International Journal of Education \&

Multidisciplinary Studies

ISSN 2455-2526; Vol.09, Issue 01 (October, 2017)

Pg. no. 1-7

Institute of Research Advances

http://research-advances.org/index.php/IJEMS

\title{
Isolation of Factors Differentiating High and Low Levels of Performance of Students in Sarva Shiksha Mission of Hooghly District of West Bengal
}

\author{
Smt. Sanghamitra Basak ${ }^{1} \&$ Prof. Prasenjit Deb ${ }^{2 \#}$ \\ ${ }^{1}$ Assistant Professor, Surendranath Women's College, Kolkata \& Scholar, University of Kalyani, India. \\ ${ }^{2}$ Supervisor \& Head, Department of Lifelong Learning \& Extension, University of Kalyani, India \\ \#corresponding author. \\ Type of Review: Peer Reviewed. \\ DOI: http://dx.doi.org/10.21013/jems.v9.n1.p1 \\ How to cite this paper: \\ Basak, S., Deb, P. (2017). Isolation of Factors Differentiating High and Low Levels of Performance of \\ Students in Sarva Shiksha Mission of Hooghly District of West Bengal. IRA International Journal of \\ Education and Multidisciplinary Studies (ISSN 2455-2526), 9(1), 1-7. doi: \\ http://dx.doi.org/10.21013/jems.v9.n1.p1
}

(C) Institute of Research Advances.

\section{(cc) EY-NC}

This work is licensed under a Creative Commons Attribution-Non Commercial 4.0 International License subject to proper citation to the publication source of the work.

Disclaimer: The scholarly papers as reviewed and published by the Institute of Research Advances (IRA) are the views and opinions of their respective authors and are not the views or opinions of the IRA. The IRA disclaims of any harm or loss caused due to the published content to any party.

Institute of Research Advances is an institutional publisher member of Publishers Inter Linking Association Inc. (PILA-CrossRef), USA. The institute is an institutional signatory to the Budapest Open Access Initiative, Hungary advocating the open access of scientific and scholarly knowledge. The Institute is a registered content provider under Open Access Initiative Protocol for Metadata Harvesting (OAI-PMH).

The journal is indexed \& included in WorldCat Discovery Service (USA), CrossRef Metadata Search (USA), WorldCat (USA), OCLC (USA), Open J-Gate (India), EZB (Germany) Scilit (Switzerland), Airiti (China), Bielefeld Academic Search Engine (BASE) of Bielefeld University, Germany, PKP Index of Simon Fraser University, Canada. 


\begin{abstract}
After flourishing execution of District Primary Education Programme (1997-2002) at the primary level, a demand had been generated at the elementary level throughout the country. To meet the demand, Sarva Shiksha Mission had been launched in 2002 throughout the country as a flagship programme where both the Union Government and the Provincial Government joined in hand at the operational level. The present study has been conducted in the eastern and western part of Hooghly district of the state of West Bengal where eastern part of the district is taken as high level of performance of students and western part of the district is taken as low level of performance of students. To illustrate the performance level of elementary students in Sarva Shiksha Mission in term of 25 variables, viz., Age $\left(X_{1}\right)$, Calorie intake value $\left(X_{2}\right)$, Food intake value $\left(X_{3}\right)$, Body Mass Index $\left(X_{4}\right)$, Mother's Education $\left(X_{5}\right)$, Use of teaching learning material at school $\left(X_{6}\right)$, Communication to School $\left(X_{7}\right)$, Mode of communication $(X 8)$, attitude of teachers towards students $\left(X_{9}\right)$, Adequate Dress during school time $\left(X_{10}\right)$, Role of School teachers in understanding text books $\left(X_{11}\right)$, Role of parents in understanding text books $\left(X_{12}\right)$, Access to text $\left(X_{13}\right)$, Availability of text books $\left(X_{14}\right)$, Home environment $\left(X_{15}\right)$, Financial Condition $\left(X_{16}\right)$, Encouragement by the social leaders toward education $\left(X_{17}\right)$, Encouragement by mother toward Education $\left(X_{18}\right)$, Encouragement by the siblings towards Education $\left(X_{19}\right)$, Contribution of mother towards study $\left(X_{20}\right)$, Contribution of mother towards study $\left(X_{21}\right)$, mother's level of income $\left(X_{22}\right)$, encouragement of mother in continuing education $\left(X_{23}\right)$, Attitude of mother towards children $\left(X_{24}\right)$, Whether engagement in essential household activities $\left(X_{25}\right)$, were found to bear substantial impact on the high and low level of performance $(Y)$ of students.
\end{abstract}

Keywords: SSM, UEE, Calorie intake value, Discriminant analysis, BMI, etc.

\title{
Introduction
}

In order to universalize the elementary educational programme, the Government of India adopted District Primary Education Programme (DPEP) in 1990s. With the success of DPEP in some parts of the country, the Government of India has implemented Sarva Shiksha Mission in 2002. The prime concern of the mission is to bring every children of the age group 6-14 years and enroll them to the elementary schools. The goals of the SSA Mission are: i) Enrolment of all children in school, Education Guarantee Centre, Alternate school,' Back- to- School' camp by 2005 ; ii) Retention of all children till the upper primary stage by 2010; iii) Bridging of gender and social category gaps in enrolment, retention and learning; and iv) Ensuring that there is significant enhancement in the learning achievement levels of children at the primary and upper primary stage.

In the study of Joshi \& Moharir (2013), Sarva Shiksha Abhiyan is an effort to recognize the need for improving the performance of the school system and to provide community owned quality elementary. They found that the mean achievements of boys, girls, rural and urban, of class III Marathi, in the district have shown positive significant changes during MAS as compared to the performance achievements during BAS. As regards SC students the mean achievement performance in Marathi during MAS was very significant as compared to BAS but in case of ST students the change was exceedingly significant. The study also revealed that the mean achievements of boys, girls, and rural of class III Maths, in the district have shown remarkable change during MAS as compared to the performance achievements during BAS. The performance in urban was insignificant. The mean percentage achievement in Maths of SC students was noteworthy whereas there was extremely significant improvement of achievement in Maths by ST students in MAS as compared to BAS. ${ }^{1}$

Roy Chowdhury (2014) found that in this paper an attempt has been made to frame out the various role played by Sarva Shiksha Mission in the development of primary education and also to point out the various aspects of school infrastructural development which would sustain the better development of primary literacy drive in near future in the city of Kolkata. He concluded that the Sarva Siksha Mission has taken lot of beneficial programme for the development of primary schools as well as primary school learners but due to proper maintenance of the school building, lack of awareness among the guardians and backward strategic tendency act as constraints in the primary

1 an empirical study of impact of Sarva Shiksha Abhiyan on the subject performance in rural and urban schools, a critical evaluation from base line assessment to midterm assessment in Nagpur district. 
literacy profile. Education is one of the facets of infrastructure, so it has never been considered as a profitable business, to follow this rule several initiative programmes should be taken by the Sarva Siksha Mission for the betterment of primary literacy drive near future in the city of Kolkata. ${ }^{2}$

According to Gogoi and Bhuya (2015), this paper looks at the status of basic infrastructure facilities provided by Sarva Shiksha Abhiyan in the primary schools of Assam with special reference to Nalbari, Sonitpur, Jorhat, and Dibrugarh District and found that there exist differences in infrastructure before and after implementation of SSA in the elementary schools of Assam. SSA has taken measures to provide more and more facilities to the schools. However, differences prevail amongst the schools. This may be due to improper management and unequal monitoring process. In the survey it has found that in majority of schools facilities for separate classrooms for different classes were not available ${ }^{3}$.

\section{Methodology of the study}

The present study is based on intensive individual survey conducted during January to August 2016 in 40 different secondary schools of Hooghly District of West Bengal which were selected on random basis out of 1038 elementary schools. A structured schedule containing of 53 different cluster of questions were placed before respondents. Generally, students of elementary Schools were selected as respondents. For the purpose of the study, two blocks from eastern part of Hooghly districts namely, Chanditala-I and Mogra-Chinsurah and another two blocks from western part of the districts namely, Pursurah and Khanakul-II were selected at random basis. From each block, ten schools were identified and from each school, ten students were selected as respondents. While calculating the high and low level of performance of Students, Chanditala-I and Mogra-Chinsuraha blocks were taken as high level of performance of the respondents and Pursurah and Khanakul-II blocks of the Hooghly District were chosen to close proximity to low level of performance of respondents. The data as collected through structured schedules were quantified and subsequently statistically analyzed by adopting Mean, Correlation, and Mahalanobis D-Square analysis method.

\section{Objectives of the study}

The main objectives of this specific study are as follows:

1. To assess the high level of performance of students of eastern part of Hooghly district specially in two blocks namely, Chinditala-I and Mogra-Chinsurah from some socio-economic, socio-cultural, and other factors associated with secondary school education system;

2. To assess the low level of performance of students of western part of Hooghly district specially in two blocks namely, Pursurah and Khanakul-II from some socio-economic, socio-cultural, and other factors associated with secondary school education system;

3. To evaluate the difference of their level of performance of students of two different regions of Hooghly district of the State of West Bengal ; and

4. To identify the factors responsible for the high and low level of performance.

\section{Result and Discussion}

\section{Table - I: Values of Linear Discriminant Coefficient against 25 casual variables}

\section{Variables}

Age $\left(\mathrm{X}_{1}\right)$

Calorie intake value $\left(\mathrm{X}_{2}\right)$

Food intake value $\left(\mathrm{X}_{3}\right)$

Body Mass Index $\left(\mathrm{X}_{4}\right)$

Mother Education $\left(\mathrm{X}_{5}\right)$

Use of teaching learning material at school $\left(\mathrm{X}_{6}\right)$

\section{Linear Difference of Coefficient}

0.04328

$-0.09093$

0.16505

0.18556

0.0288

$-0.10975$

\footnotetext{
2 Sarva Siksha Mission and Primary Education in Kolkata: Changes and Challenges.

${ }^{3}$ Development of infrastructure in elementary schools of Assam under Sarva Shiksha Abhiyan
} 
Communication to School $\left(\mathrm{X}_{7}\right)$

Mode of communication $\left(\mathrm{X}_{8}\right)$

Attitude of teachers towards students $\left(\mathrm{X}_{9}\right)$

Adequate Dress during school time $\left(\mathrm{X}_{10}\right)$

Role of School teachers in understanding text books $\left(\mathrm{X}_{11}\right)$

Role of parents in understanding text books $\left(\mathrm{X}_{12}\right)$

Access to text $\left(\mathrm{X}_{13}\right)$

Availability of text book $\left(\mathrm{X}_{14}\right)$

Home environment $\left(\mathrm{X}_{15}\right)$

Financial Condition $\left(\mathrm{X}_{16}\right)$

Encouragement by the social leaders toward education $\left(\mathrm{X}_{17}\right)$

Encouragement by mother toward Education $\left(\mathrm{X}_{18}\right)$

Encouragement by the siblings towards Education $\left(\mathrm{X}_{19}\right)$

Contribution of mother towards study $\left(\mathrm{X}_{20}\right)$

Whether your mother help you during study $\left(\mathrm{X}_{21}\right)$

Mother's level of income $\left(\mathrm{X}_{22}\right)$

Encouragement of mother in continuing education $\left(\mathrm{X}_{23}\right)$

Attitude of mother towards children $\left(\mathrm{X}_{24}\right)$

Whether engagement in essential household activities $\left(\mathrm{X}_{25}\right)$
$-0.20046$
$-0.01097$
0.1184
0.29557
0.2856
0.66873
$-0.04351$
0.11907
$-0.54497$
$-0.3899$
0.25217
0.09149
0.03955
0.0389
0.18193
$-0.01261$
$-0.24233$
$-0.01273$
0.00628

Table I shows the $\mathrm{D}^{2}$ based statistics on the twenty five variables. Values of coefficients and Discriminant function of factors discriminate the student's of two regions of Hooghly district of West Bengal in terms of their level of performance of students during Sarva Shiksha Mission and its utility towards fulfillment of the objectives of Universalization of elementary education. The tabulated $\mathrm{D}^{2}$ values at 398 degrees of freedom have implied that the 25 variables considered in distinguishing the two levels of student's having high and low participation level were influential.

Table - II: Means, their differences and ' $r$ ' values of variables with respect to attitudinal levels.

\begin{tabular}{|c|c|c|c|c|}
\hline Variables & $\begin{array}{l}\text { High Level } \\
N_{1}=200\end{array}$ & $\begin{array}{l}\text { Low Level } \\
\mathbf{N}_{2}=200\end{array}$ & $\begin{array}{l}\text { Mean } \\
\text { Difference (MD) }\end{array}$ & 'r' value \\
\hline$X_{1}$ & 10.34 & 8.73 & 1.61 & $0.1241 *$ \\
\hline $\mathrm{X}_{2}$ & 18.60 & 19.46 & -0.86 & -.0055 \\
\hline $\mathrm{X}_{3}$ & 2.25 & 2.24 & 0.01 & 0.0021 \\
\hline$X_{4}$ & 20.05 & 13.31 & 6.74 & -.0422 \\
\hline$X_{5}$ & 2.50 & 2.07 & 0.43 & $0.1301 * *$ \\
\hline$X_{6}$ & 2.52 & 2.42 & 0.1 & $0.1210 * *$ \\
\hline $\mathbf{X}_{7}$ & 2.34 & 2.28 & 0.06 & $0.1052 *$ \\
\hline $\mathrm{X}_{8}$ & 2.09 & 2.2 & -0.11 & 0.0304 \\
\hline$X_{9}$ & 2.34 & 2.03 & 0.31 & $0.0122 *$ \\
\hline $\mathrm{X}_{10}$ & 2.49 & 2.35 & 0.15 & -0.0015 \\
\hline$X_{11}$ & 4.67 & 5.14 & -0.47 & $-0.2037 * *$ \\
\hline$X_{12}$ & 4.41 & 7.8 & -3.39 & $-0.3460 * *$ \\
\hline$X_{13}$ & 7.28 & 7.52 & -0.24 & $-0.1315 * *$ \\
\hline $\mathrm{X}_{14}$ & 5.97 & 5.76 & 0.21 & 0.0558 \\
\hline$X_{15}$ & 3.45 & 4.14 & -0.69 & $0.1051^{*}$ \\
\hline$X_{16}$ & 3.27 & 3.29 & -0.02 & $0.1839 * *$ \\
\hline $\mathrm{X}_{17}$ & 2.02 & 2.03 & -0.01 & -0.0665 \\
\hline $\mathrm{X}_{18}$ & 2.26 & 1.97 & 0.3 & -0.0159 \\
\hline $\mathrm{X}_{19}$ & 2.36 & 2.28 & 0.09 & 0.0311 \\
\hline$X_{20}$ & 6.03 & 5.70 & 0.33 & -0.0776 \\
\hline$X_{21}$ & 5.29 & 5.90 & -0.61 & 0.0274 \\
\hline$X_{22}$ & 1.77 & 1.79 & -0.02 & 0.0323 \\
\hline $\mathbf{X}_{23}$ & 2.51 & 2.54 & -0.03 & 0.1012* \\
\hline$X_{24}$ & 2.62 & 2.38 & 0.24 & 0.0731 \\
\hline
\end{tabular}




$\begin{array}{lllll}\mathrm{X}_{25} & 1.27 & 1.53 & -0.26 & -0.0040\end{array}$

*Significant at $5 \%$ level $(r=0.098)$

** Significant at $1 \%$ level $(\mathbf{r}=\mathbf{0 . 1 2 8})$

The results in the above table give the mean values and their differences with significance of 25 variables for high and low level of performance among students of eastern and western region of Hooghly District of West Bengal. The high performance level means the higher awareness and deeper understanding about their own study as well as the overall activities of Sarva Shiksha Mission and on the other hand low performance level means the lower awareness and superficial understanding about their own study and about the overall activities of SSM. Here, in this table, high level of performance always does not necessarily to carry the high value and the same is true for the low level performance to carry the low value.

Out of these twenty five variables, 11 variables viz. Age $\left(\mathrm{X}_{1}\right)$, Mother Education $\left(\mathrm{X}_{5}\right)$, Use of teaching learning material at school $\left(\mathrm{X}_{6}\right)$, Communication to School $\left(\mathrm{X}_{7}\right)$, attitude of teachers towards students $\left(\mathrm{X}_{9}\right)$, Role of School teacher in Understanding text books $\left(\mathrm{X}_{11}\right)$, Role of parents in understanding text books $\left(\mathrm{X}_{12}\right)$, Access to text $\left(\mathrm{X}_{13}\right)$, Home environment $\left(\mathrm{X}_{15}\right)$, Financial Condition $\left(\mathrm{X}_{16}\right)$, encouragement of mother in continuing education $\left(\mathrm{X}_{23}\right)$ showed their significant level of impact in differentiating the high and low level of performance among students of two different regions of Hooghly District of West Bengal.

The mean values of age of students of elementary classes of eastern and western region of Hooghly district are 10.345 and 8.73 respectively. The high mean value of $X_{1}$ indicates that the overall maturity of students of the eastern region of the district is higher than their counterpart of Western region. Thus, this factor contributes the positive correlational effect on the level of discrimination among the two regions.

Though mothers of students of eastern part of Hooghly posses comparatively higher education than their counterpart of western region. Higher qualification of mother means the higher involvement and better understanding regarding the education of her child. Hence, the critical value of correlation of $X_{5}$ is $0.1301 * *$ which indicates that the factor like mothers education also played the crucial role in segregating the high and low level of performance among their children.

Again the mean value of the variable $X_{6}$ has the higher value (2.525) in eastern part of the district. This implies that the factor Use of teaching learning material at school $\left(\mathrm{X}_{6}\right)$ has played a very prominent role in understanding the text book and access to text for the students of two blocks from eastern part of Hooghly district. Hence, this variable shows the positive bearing on the predictor variable.

The mean value of Communication to School $\left(\mathrm{X}_{7}\right)$ in the eastern part of the district is 2.34 and the same for the western part of the district is 2.28 The higher mean value of Communication to School $\left(\mathrm{X}_{7}\right)$ indicates that the eastern part of Hooghly district has better communication in compare to the western part of the same district. Better communication to school is again corroborative with the level of performance of students and hence it is rightly distinguished between the high and low level of the performance of students in two different regions of the district.

Attitude of teachers towards students $\left(\mathrm{X}_{9}\right)$ has the higher mean value in two blocks of eastern part than their counter parts of two blocks of western part of Hooghly district. Also the critical value of correlation finds its positive impact which indicates that positive attitudes of teachers towards students help in understanding the text book as well as students understand the meaning of education and joyful learning.

The mean value of the variable such as role of school teacher in understanding text books $\left(\mathrm{X}_{11}\right)$ in the eastern part of the district shows its higher value than their counterpart of western region of the district. This variable shows its negative impact in determining the differentiation between high and low level of performance of students.

The mean value of $\mathrm{X}_{12}$ in eastern part is 4.415 whereas the same for western part is 7.8 Thus, the critical value of correlation is found $-0.3460^{* *}$ which indicates that its impact is negative. Role of parents in understanding 
text books $\left(\mathrm{X}_{12}\right)$ shows its negative value means parents in this study fail to explain in discriminating the high and low value of performance of students between the two regions of Hooghly district.

Similar to the variables $X_{11}$ and $X_{12}$, the variable like Access to text $\left(X_{13}\right)$ by students has also shown its lower mean value of eastern region of the district than their counterpart of western region of Hooghly district. As a result the critical value of coefficient of correlation also shows its strong negative impact in differentiation the statement of the problem.

The variable $\mathrm{X}_{15}$ showed its positive impact in determining the high and low value of performance of students between the two regions of Hooghly district. The positive correlation value indicates that the adequate home environment would enhance the level of educational performance of students of the district Hooghly.

Financial Condition $\left(\mathrm{X}_{16}\right)$ had shown its strong positive consequence in determining the statement of the problem. The positive correlational value indicates that the variable $\mathrm{X}_{16}$ helps in achieving the better education. Thus, the factor like Financial Condition $\left(\mathrm{X}_{16}\right)$ has shown its contribution towards the isolation among the high and low value of performance of students between the two regions of Hooghly district.

Encouragement of mother in continuing education $\left(\mathrm{X}_{23}\right)$ has the prominent for their children in continuing their course of study. In all practical cases, mothers are not able in helping directly for the educational growth of their children. But it helps for the students in acquiring the education and for positive motivation towards education.

Table - III: Percentage Contribution of Individual Character to the Total Distance Measurement.

\begin{tabular}{|c|c|c|c|c|c|}
\hline Code & Variables & Mean & Mean & Percentage & Rank \\
\hline No. & Coefficient $\left(\mathrm{D}^{2}\right)$ & Difference & Difference $x \mathrm{D}^{2}$ & Contribution & \\
\hline $\mathrm{X}_{1}$ & 0.04328 & 1.61 & 0.0696808 & 1.55 & VII \\
\hline $\mathrm{X}_{2}$ & -0.09093 & -0.86 & 0.0781998 & 1.74 & VI \\
\hline$X_{3}$ & 0.16505 & 0.01 & 0.0016505 & 0.04 & \\
\hline $\mathrm{X}_{4}$ & 0.18556 & 6.74 & 1.2506744 & 27.75 & II \\
\hline $\mathrm{X}_{5}$ & 0.0288 & 0.43 & 0.012384 & 0.27 & \\
\hline$X_{6}$ & -0.10975 & 0.1 & 0.010975 & 0.24 & \\
\hline$X_{7}$ & -0.20046 & 0.06 & 0.0120276 & 0.27 & \\
\hline $\mathrm{X}_{8}$ & -0.01097 & -0.11 & 0.0012067 & 0.03 & \\
\hline $\mathrm{X}_{9}$ & 0.1184 & 0.31 & 0.036704 & 0.81 & \\
\hline$X_{10}$ & 0.29557 & 0.15 & 0.0443355 & 0.98 & \\
\hline $\mathrm{X}_{11}$ & 0.2856 & -0.47 & 0.134232 & 2.98 & IV \\
\hline $\mathrm{X}_{12}$ & 0.66873 & -3.39 & 2.2669947 & 50.30 & I \\
\hline$X_{13}$ & -0.04351 & -0.24 & 0.0104424 & 0.23 & \\
\hline$X_{14}$ & 0.11907 & 0.21 & 0.0250047 & 0.55 & \\
\hline$X_{15}$ & -0.54497 & -0.69 & 0.3760293 & 8.34 & III \\
\hline $\mathrm{X}_{16}$ & -0.3899 & -0.02 & 0.007798 & 0.17 & \\
\hline$X_{17}$ & 0.25217 & -0.01 & 0.0025217 & 0.06 & \\
\hline $\mathrm{X}_{18}$ & 0.09149 & 0.3 & 0.027447 & 0.61 & \\
\hline $\mathrm{X}_{19}$ & 0.03955 & 0.09 & 0.0035595 & 0.08 & \\
\hline$X_{20}$ & 0.0389 & 0.33 & 0.012837 & 0.28 & \\
\hline$X_{21}$ & 0.18193 & -0.61 & 0.1109773 & 2.46 & $\mathrm{~V}$ \\
\hline$X_{22}$ & -0.01261 & -0.02 & 0.0002522 & 0.01 & \\
\hline $\mathrm{X}_{23}$ & -0.24233 & -0.03 & 0.0072699 & 0.16 & \\
\hline$X_{24}$ & -0.01273 & 0.24 & 0.0030552 & 0.07 & \\
\hline $\mathrm{X}_{25}$ & 0.00628 & -0.26 & 0.0016328 & 0.04 & \\
\hline
\end{tabular}

Table III showed the percentage contribution of each variable to the total discrimination. Out of the 25 variables, three variables such as Role of parents in understanding text books (50.30\%), Body Mass Index (27.75\%), Home environment (8.34\%), Role of School teachers in understanding text books (2.98\%), Contribution of mother 
towards study (2.46\%), Calorie intake value (1.74\%) and Age (1.55\%) in a cluster contributed more than 95.12 per cent towards the total discrimination. Hence, role of parents in understanding text books, Body Mass Index, Home environment, role of School teachers in understanding text books, contribution of mother towards study, and calorie intake value have been found to be key discriminators and planners and executors of Sarva Shiksha Mission should pay attention on these factors in dealing with the problem of high and low level performance among students of two different regions of Hooghly district of West Bengal.

\section{Conclusion}

From the study of Das and Deb (2015), it is found that age necessity of private tuition, reason behind private tuition, number of drawback of secondary education, social awareness, additional boost up by RMSA, effectiveness of SSA/SSM, Mid-Day Meal for secondary level, and successful execution of Mid-Day meal in a cluster contributed significantly in Segregating High and Low Level of Perception among students of Kolkata and Uttar Dinajpur district about Rashtriya Madhyamik Shiksha Abhiyan. ${ }^{4}$ The present study, however, isolates between the high and low level of performance among students of two different regions of the same district. It is found that 11 variables viz. Age, Mother's Education, Use of teaching learning material at school, Communication to School, attitude of teachers towards students, Role of School teachers in Understanding text books, Role of parents in understanding text books, Access to text, Home environment, Financial Condition, and encouragement of mother in continuing education are found to be significant while showing correlational value. On the other hand the five variables such as Role of parents in understanding text books, Body Mass Index, Home environment, Role of School teachers in understanding text books, Contribution of mother towards study, Calorie intake value and Age have been identified through rank matrix analysis in differentiating high and low level of performance among students of two different regions of Hooghly district of West Bengal. It is also found that there are some factors which have shown there unpredictable nature towards the statement of the problem. This study would help the policy planners and administrators of Hooghly district in specific and the State of West Bengal in general to execute the programme like Sarva Shiksha Mission.

\section{References}

[1] Joshi, Vijoy \& Moharir, Kishor. (2013). An empirical study of impact of Sarva Shiksha Abhiyan on the subject performance in rural and urban schools, a critical evaluation from base line assessment to midterm assessment in Nagpur district. National Monthly Refereed Journal of Research in Commerce \& Management.

[2] Roy Chowdhury, Indrajit. (2014). Sarva Siksha Mission and Primary Education in Kolkata: Changes and Challenges. International Journal of Humanities and Social Science Invention, 3(11), pp. 70-81.

[3] Gogoi, Manjuri and Bhuya, Sailendra. (2015). Development of infrastructure in elementary schools of Assam under Sarva Shiksha Abhiyan. SRJIS,pp.542

[4] Das, Premendra and Deb, Prasenjit (2015). Segregation of Factors Differentiate High and Low Level of Perception among Student's about Rashtriya Madhyamik Shiksha Abhiyan, International Journal of Research in Economics and Social Sciences, pp. 59-66.

\footnotetext{
${ }^{4}$ Segregation of Factors Differentiate High and Low Level of Perception among Student's about Rashtriya Madhyamik Shiksha Abhiyan
} 